\title{
Sensitivity Analysis of Broiler Farming Enterprise under Changing Scenario of Costs, Prices and Yields in Assam
}

\author{
Monisha Borah ${ }^{1 *}$ and R. A. Halim ${ }^{2}$ \\ ${ }^{1}$ All India Coordinated Research Project on Integrated Farming Systems (AICRP-IFS), \\ ${ }^{2}$ Department of Agricultural Economics and Farm Management, Assam Agricultural \\ University, Jorhat, Assam \\ *Corresponding author
}

\section{A B S T R A C T}

\section{Keywords}

Broiler farm, Break even analysis, PBP, NPV, BCR, IRR, Sensitivity analysis

Article Info

Accepted:

12 December 2020 Available Online: 10 January 2021
Present study was carried out in Sonitpur district of Assam by collecting farm level data from 100 broiler farmers during 2012. Initially, economic appraisal of broiler farms was carried out conducting break even analysis and investment appraisal (computing Pay Back Period, Net Present Value, Benefit Cost Ratio and Internal Rate of Return) in each of the sample farms. Subsequently, to examine the effect of changes in cost, yield and return structure on the existing economic performance of the broiler farms, sensitivity analysis was carried out by re-working all the break even values and investment appraisal tools under different scenario of yield, price and cost changes. The break even analysis reveal that although all the farms in their existing condition of average prices and production were well above all the break even values in terms of price, quantity produced (in $\mathrm{Kg}$ live weight and number of birds), volume of meat produced and number of years required to cover the investment cost, however, if the production falls by $25 \%$ of the existing production of birds, none of the farms in any size groups remains economically viable. Similarly, if price of the bird falls below $15 \%$ of the existing price, small sized farms (Group I and II) do not recover from the business, while large ones still remains profitable and viable in the business. PBP, NPV, BCR and IRR values computed under changing cost and return structure, showed that large farms were relatively less sensitive to changes in costs and returns, while smaller farms became unviable especially when both costs were increased by $5 \%$ and returns decreased by $5 \%$ simultaneously.

\section{Introduction}

In resemblance with other states of the North Eastern region of the country, people in Assam have their own traditional reservation for all poultry products in their daily diets. Broiler farming has attained popularity in the state among the farmers because of the attributes like high feed conversion efficiency of broiler bird, low initial investment, less rearing space requirement and faster return etc. besides escalating demand from the consumer side (Borah and Halim, 2017). Since, a larger section of the agrarian population in the state comprises marginal farmers, small farmers and landless labourers 
possessing highly fragmented land holdings, broiler farming assumes special significance in view of income and employment generation in the state both in principal as well as subsidiary status. Risks and uncertainties are inherent to agricultural production because of its biological nature and broiler farming is not an exception to this. Probability of disease incidence particularly sudden outbreak of some deadly diseases is quite high in broiler farming and is perceived as a severe problem. In case of broilers the disease needs to be diagnosed and treated immediately on the incidence. Any delay in diagnosis and prescribed treatment along with improper hygienic and sanitation measure undertaken could lead to a ruin of the enterprise (Kalita, 2011). Further, price of the output may also fluctuate due to changing consumer demand owing to disease outbreak, health issues and other market and institutional issues etc. Thus, in addition to the assessment of economic viability of an enterprise in terms of income and employment generation potential, evaluation of its competence in handling probable production and market related risks is also crucial, especially when the enterprise tend to be highly susceptible besides being an integral part of farming systems of farmers. While there are many strategies in existence in avoiding or combating risky situations, an enterprise can tolerate fall in production and price of the output up to a considerable extent if the economic condition is sound enough with its production well above the break even level. Break even analysis is an important tool to evaluate economic viability of any enterprise, however this analysis relies on the assumption of constant factor prices, constant technology and constant selling prices. This is a limitation as prices, costs and production changes over time. Hence, there is a need to consider and incorporate the probable changes in the relevant data on production and prices required for economic evaluation as a part of the analysis. This would illustrate the potentiality of an enterprise in standing against sudden fluctuations in price and production and would also indicate the extent of such fluctuations that can be tolerated by the enterprise in question. Further, While, the financial soundness or the profitability of an enterprise can be best examined by analyzing the cash flow during the assumed life of the investment, using different investment appraisal tools like payback period (PBP), benefit - cost ratio (BCR), net present value (NPV) and internal rate of return (IRR), however, probable fluctuations in future price and production may render such assessment unrealistic and worthless as time is an unavoidable element in such analysis and this type of analysis is generally carried over a period. According to Reddy et al., 2010, "Project appraisal techniques provide us certain measure of project's worth, which is related to a certain period of time and projects are measured under the assumption that the data used in the project evaluation remain unchanged over a length of time but in reality this is not a valid assumption as cost and returns go awry over time. Moreover, it is also necessary to know as to how far the estimates of appraisal obtained remain constant under changing situations of costs, prices and production Sensitivity analysis gives answers to such questions" (Reddy et al., 2010). Thus, in the words of Kay (1986), "given the uncertainty that may exist in the future production, prices and costs, used to estimate net cash revenues and the terminal values, it is often useful to look at what would happen to net present value if the prices and costs were different" (Kay, 1986). Such analysis would again aid in understanding the capability of an enterprise in tolerating probable fluctuations in price, cost and yield related to its products. Therefore, in the present study a sensitivity analysis was carried out to incorporate the changes in prices of the products, production of the 
output in the break even values estimated to appraise the economic viability of broiler farming. Further, as a part of the sensitivity analysis in regard to investment appraisal, probable changes in costs of input $\&$ prices of output (returns) were also incorporated to see their impact on payback period (PBP), net present values (NPV), internal rate of return (IRR) and benefit-cost ratios (BCR) estimated to appraise the economic viability of broiler farming enterprise in Sonitpur district of Assam.

\section{Materials and Methods}

The present study was carried out in 100 randomly selected broiler farms of Sonitpur district of Assam. Sonitpur district accounted for the second highest population of fowls in the state of Assam as per 2003-04 sample survey and there are limited studies on the economic aspects of broiler farming in the district. Stratified random sampling design was used in the selection of samples in the present study. At first, 513 commercial broiler farms in total, which had been in production continuously for at least one year in Sonitpur district, were identified. Out of the total farms identified, $20 \%$ of the broiler farms accounting for approximately 100 in numbers were selected at random for the study. The selected sample broiler farms were again stratified into four size groups using the cumulative frequency distribution method. With the total frequency of 100 farms, the groups were so constructed that each group composed roughly of equal numbers of farms. The stratification is shown in Table 1.

The relevant primary data on cost, production, returns and other economic aspects of broiler farming pertaining to the year 2011-12 were collected from the selected broiler farmers using specially designed pre-tested schedules and questionnaires through personal interview with the respondent farmers.
In the current study, data on production, cost and returns relate to one production cycle and as such relevant calculations were done considering one production cycle of 6 weeks (Kalita, 2011).

The major analytical tool employed for the study was tabular analysis. Economic analysis was conducted by computing cost of production in broiler farming in terms of variable cost, fixed cost and total cost incurred per cycle and returns in terms of gross and net return. Break even analysis was carried out for price, production (kg live weight \& number of birds), volume of output produced and number of years required to recover the initial investments using the following formulae:

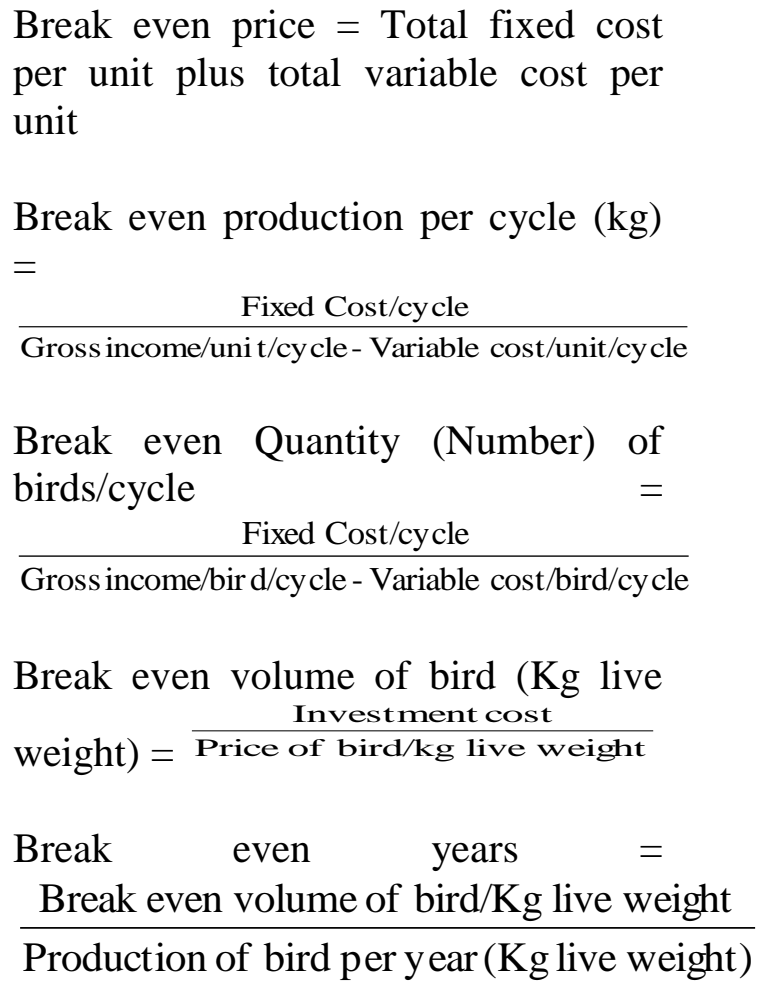

Moreover, payback period (PBP), net present value (NPV), benefit-cost ratio (BCR) and internal rate of return (IRR) were estimated to appraise the profitability of broiler farming enterprise using standard procedures as below: 
$P=\frac{I}{E}$

Where, $\mathrm{P}=$ Payback period of the project in years

I = Investment on the project in rupees

$=$ Annual net cash revenue in rupees

The preference of a particular project is based on shorter payback period.

Net Present Value $(N P V)=\sum_{t=1}^{n} \frac{\mathbf{B}_{n}-\mathbf{C}_{n}}{(\mathbf{1}+\mathbf{i})^{n}}$

Where,

$\mathrm{B}_{\mathrm{n}}=$ Benefits or present (discounted) value of cash inflows in each year

$\mathrm{C}_{\mathrm{n}}=$ Costs or present (discounted) value of cash outflows in each year

$\mathrm{n}=$ Number of years

$\mathrm{i}=$ Discount rate

The investment is profitable if NPV $\geq 0$, when $i \geq$ opportunity cost of capital or market value of borrowing.

Benefit Cost Ratio $(B C R)=\frac{\sum_{t=1}^{n} B_{n} /(1+i)^{n}}{\sum_{t=1}^{n} C_{n} /(1+i)^{n}}$

Where,

$B_{n}=$ Benefits or present (discounted) value of cash inflows in each year

$\mathrm{C}_{\mathrm{n}}=$ Costs or present (discounted) value of cash outflows in each year

$\mathrm{n}=$ Number of years

$\mathrm{i}=$ Discount rate

The investment is profitable when the BCR is one or greater than one i.e. $\mathrm{BCR} \geq 1$.

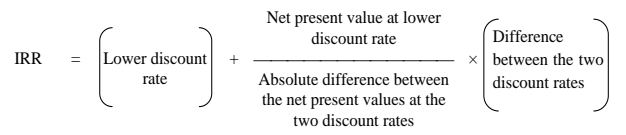

The investment is profitable when the internal rate of return (IRR) is greater than opportunity cost of capital or market value of borrowing.

Further, sensitivity analysis was carried out for $10 \%, 25 \%$ and $50 \%$ levels of changes in production and $5 \%, 10 \%$ and $25 \%$ levels of changes in price in case of break even analysis. For investment appraisal, sensitivity analysis was carried out for $5 \%$ increase in cost, $5 \%$ decrease in return and $5 \%$ increase in cost and $5 \%$ decrease in return together.

\section{Results and Discussion}

\section{Cost and return structure of broiler farming}

Economic analysis that comprises mainly examination of cost and return structure of individual farms, forms the basis for all subsequent analysis of the study namely break even analysis, investment appraisal and sensitivity analysis of the sample broiler farms. Since investigation of economic aspects at individual farm level underlines the basic analytical foundation of the present study, thus estimation of cost and returns structure of each individual broiler farms is the prerequisite for any further analysis. Therefore, in order to have an understanding of the primary economic aspects of the sample broiler farms, cost of production and returns from the output for each group of sample farms is presented in the following section.

\section{Cost of production}

The cost of broiler production in terms of variable cost, fixed cost and total cost incurred per cycle were worked out and presented in Table 2. Data from the table reveal that, on an average total variable cost, total fixed cost and total cost for the entire 
sample were found to be Rs. 125.55, Rs. 9.11 and Rs. 134.66 per bird per cycle respectively. Total variable cost per $\mathrm{kg}$ live weight and per bird per cycle were worked out as Rs. 62.55, 134.72; Rs. 58.76, 126.57; Rs. 58.17, 125.63 and Rs. 56.85; 124.57 respectively in Group I to Group IV. Similarly, total cost of production per bird per cycle were computed as Rs. 143.54, 138.23, 135.40 and 132.78 in Group I, II, III and IV respectively.

Thus, size group wise total variable cost and total cost per $\mathrm{kg}$ of meat produced and per whole bird showed a decreasing trend along with increasing farm size indicating an inverse relationship between farm size and cost of production. This is in conformity with the findings of Singh et al (2010)

\section{Returns}

Table 3 presents the details of gross return, return over variable cost and net return from broiler production per farm, per bird and per $\mathrm{kg}$ live weight per cycle in the sample. Total gross return from broiler farming comprises return from meat and return from by products. Poultry manure and the gunny bags used in broiler rearing are the by-products of broiler farming. A perusal of the table reveal that total gross return, return over variable cost and net return per bird per cycle were worked out as Rs. 164.91, Rs. 49.43 and Rs. 30.25 respectively for the sample as a whole. Size group wise, although total gross return per bird per cycle is similar throughout all the size groups of farms; however a clear increasing trend along the increasing size groups could be seen in case of return over variable cost and net return per bird per cycle. Increasing net return and return over variable cost with higher sized groups could be attributed to comparatively low variable cost of production in case of higher sized group.

\section{Sensitivity analysis}

Sensitivity analysis of the sample broiler farms under changing situations of costs, price and yield was carried out to observe the impact of fluctuations in production, price of output as well as input on economic performance and viability of sample broiler farms. In the first stage, existing economic position and viability status of the sample farms was investigated through break even analysis and computing investment appraisal tools like Pay Back Period (PBP), Net Present Value (NPV), Benefit Cost Ratio (BCR) and Internal Rate of Return (IRR).

Secondly the competence of the sample farms in tolerating price and production fluctuations were examined by imposing different level of price and production changes on break even values and investment appraisal tools. All break even values and investment appraisal tools were reworked under changing conditions of price and production and the detail of the analysis is presented in the following sections.

\section{Effect of changes in price and production of output on break even values}

Economic feasibility of an enterprise can be best judged by using break even analysis. In the present study, at first break even values of price, production (in terms of $\mathrm{kg}$ live weight and number of broiler birds i.e. quantity), volume of meat and years to recover the investment cost were worked out to examine the economic viability.

In the next stage, the effect of changes in price on break even production and effect of changes in production on break even prices of the output were found out with 10, 25 and 50 $\%$ level of changes in production and 5, 10 and $15 \%$ level of changes in prices of output. 


\section{Break even price}

Table 4 shows break-even price per kg live weight of broiler bird across different farm size groups. It is observed from the table that on an average break even price per $\mathrm{kg}$ live weight and per bird with the existing production was Rs. 61.88 Rs. and 134.66 respectively for the entire sample i.e. on an average the farms needs to receive Rs. 61.88 per kg live weight and Rs. 134.66 per bird only for break even while actual average price received per kg live weight was Rs. 75.00 and per bird was Rs. 163.50. Size group wise analysis also reveals that farms in all of the groups were economically viable with the existing price received per $\mathrm{kg}$ live weight and per bird being higher than the price required to be received for their viability in the business (break even price). Sensitivity analysis however brought to light that, although all the farms in all size groups could tolerate up to $10 \%$ decrease in production under existing price scenario, however, at $25 \%$ decrease in the existing production no farm could remain viable in the business. Data from Table 4 indicate that break even price of bird at $10 \%$ increase and decrease in the existing production of birds was Rs. 122.42 and Rs. 149.62 respectively. Thus, it is evident from the analysis that in the existing scenario of average selling price of birds, all the farms could survive even if the production of birds falls below $10 \%$ of the existing production.

However, none of the farms in any of the group stands economically viable if the production of birds falls below $25 \%$ of the existing production as in that case, the average price to be received for break even becomes Rs. 179.55 per bird, which is higher than the exiting average price received (Rs.163.50) per bird. Halim and Chistie (2000) also reported similar results regarding break even price in broiler farming.

\section{Break even production}

Break-even production of broiler birds was computed both on live weight (Kg) basis and as whole bird (number) in the present study and are shown in Table 5 and Table 6 respectively..

Break even production of meat in live weight basis per cycle with the existing price per kilogram of live weight was computed as 119545.32 kilogram on an average with per farm and per bird value of 1195.45 and 0.53 kilograms respectively in the entire sample (Table 5). This means on an average a farm needs to produce 1195.45 kilogram of meat and a bird needs to weigh at least 0.53 kilogram per cycle under ideal condition of zero mortality. Data from the table also reveal that the average existing production per cycle was 4942.01 kilograms per farm and 2.18 kilograms per bird and total average production in the entire sample was 494201.30 kilograms. Thus, in the existing price scenario, average production of meat in the sample is much higher than its break even value. Similarly, size group wise too, average meat production in one cycle in all the farm groups were much higher than their respective break even values per cycle with the existing price thereby indicating economic viability of all the farms with existing meat production in the existing price. Sensitivity analysis reveals that on an average break even production of meat at $5 \%$ and $10 \%$ and $15 \%$ decrease in the existing price of meat was $1526.17,2109.86$ and $3416.50 \mathrm{~kg}$ per farm and $0.67,0.93$ and $1.50 \mathrm{~kg}$ per bird respectively across the sample, indicating survival of all the farms in the existing scenario of average selling price of birds even if the production of birds falls up to $15 \%$ of the existing production as average production in the entire sample is higher than $3416.50 \mathrm{~kg}$ per farm. However, not all the farm groups remain economically viable when price falls below $15 \%$ of the 
existing. At $15 \%$ decrease in the existing price, Group I and II farms do not recover from the business, while Group III and IV still remains profitable and viable in the business. At $15 \%$ level of decrease in the existing price Group I needs to produce 71190.38 kilograms of meat as against their average production of 20892.40 kilograms and Group II needs to produce 66450.78 kilograms of meat as against their average production of 61167.40 kilograms, indicating certain degree of risk if price falls for this two groups of farms.

Table.1 Stratification of sample broiler farms into different size groups

\begin{tabular}{|c|c|c|c|}
\hline \multicolumn{2}{|c|}{ Size groups } & Number of farms in the & Percentage of the total \\
\hline a) & Group I (up to 500 birds) & 25 & 25 \\
\hline b) & Group II (501-1500 birds) & 26 & 26 \\
\hline c) & Group III (1501-3000 birds) & 26 & 26 \\
\hline d) & Group IV (3001 and above birds) & 23 & 23 \\
\hline \multicolumn{2}{|c|}{ All farms } & 100 & 100 \\
\hline
\end{tabular}

Table.2 Cost incurred per farm per cycle by different size groups of broiler farms (rupees)

\begin{tabular}{|l|c|c|c|c|c|}
\hline \multirow{2}{*}{ Cost items } & \multicolumn{5}{c|}{ Cost incurred (Rs.) by different farm size groups } \\
\cline { 2 - 6 } & Group I & Group II & Group III & Group IV & All farms \\
\hline \multirow{2}{*}{ Variable cost } & 52271.95 & 138247.99 & 309240.63 & 677015.23 & 285128.53 \\
\cline { 2 - 6 } & $(134.72)$ & $(126.57)$ & $(125.63)$ & $(124.57)$ & $(125.55)$ \\
\hline \multirow{2}{*}{ Fixed cost } & 3419.99 & 12742.94 & 24062.78 & 44621.96 & 20687.54 \\
\cline { 2 - 6 } & $(8.81)$ & $(11.67)$ & $(9.78)$ & $(8.21)$ & $(9.11)$ \\
\hline Cotal cost & 55691.94 & 150990.93 & 333303.42 & 721637.18 & 305816.07 \\
\hline & $(143.54)$ & $(138.23)$ & $(135.40)$ & $(132.78)$ & $(134.66)$ \\
\hline Vart per Kg of meat (live weight) & & & & & \\
\hline Fixed cost & 62.55 & 58.76 & 58.17 & 56.85 & 57.69 \\
\hline Total cost & 4.09 & 5.42 & 4.53 & 3.75 & 4.19 \\
\hline
\end{tabular}

Figures within parentheses indicate cost per bird

Table.3 Returns from broiler farming per cycle in different size groups of sample farms (rupees)

\begin{tabular}{|l|r|r|r|r|r|}
\hline \multirow{2}{*}{ Particulars } & \multicolumn{5}{|c|}{ Returns from different size groups of sample farms } \\
\cline { 2 - 6 } & Group I & Group II & Group III & Group IV & All farms \\
\hline Total gross returns & 63380.67 & 178248.16 & 403229.17 & 902125.50 & 374518.14 \\
\hline Returns over variable cost & $\mathbf{1 6 3 . 3 5}$ & $\mathbf{1 6 3 . 1 8}$ & $\mathbf{1 6 3 . 8 1}$ & $\mathbf{1 6 5 . 9 9}$ & $\mathbf{1 6 4 . 9 1}$ \\
& $(75.84)$ & $(75.77)$ & $(75.85)$ & $(75.75)$ & $(75.78)$ \\
\hline Net returns (Returns over total & 11108.72 & 40000.18 & 120323.67 & 294761.13 & 112256.44 \\
\hline cost) & $\mathbf{2 8 . 6 3}$ & $\mathbf{3 6 . 6 2}$ & $\mathbf{4 8 . 8 8}$ & $\mathbf{5 4 . 2 4}$ & $\mathbf{4 9 . 4 3}$ \\
& $(13.29)$ & $(17.00)$ & $(22.63)$ & $(24.75)$ & $(22.71)$ \\
\hline & & & 69925.76 & 180490.56 & 68702.59 \\
& $\mathbf{1 9 . 8 2}$ & $\mathbf{2 4 . 9 5}$ & $\mathbf{2 8 . 4 1}$ & $\mathbf{3 3 . 2 1}$ & $\mathbf{3 0 . 2 5}$ \\
\hline
\end{tabular}

Figures in bold indicate values per bird

Figures within parentheses indicate values per kg of meat (live weight) produced 
Table.4 Break even price per kilogram of live weight of broiler birds with 10, 25 and 50 per cent increase and decrease in the production across different size groups of sample broiler farms (Rs.)

\begin{tabular}{|c|c|c|c|c|c|c|c|c|}
\hline $\begin{array}{c}\text { Size } \\
\text { group }\end{array}$ & $\begin{array}{l}\text { BEP* per kg } \\
\text { of } L W^{* *} \text { with } \\
\text { the existing } \\
\text { production }\end{array}$ & $\begin{array}{l}\text { BEP* per kg } \\
\text { of } L W^{* *} \text { with } \\
10 \% \text { increase } \\
\text { over the } \\
\text { existing } \\
\text { production of } \\
\text { meat }\end{array}$ & $\begin{array}{l}\text { BEP* per kg } \\
\text { of } L W * * \text { with } \\
10 \% \text { decrease } \\
\text { over the } \\
\text { existing } \\
\text { production of } \\
\text { meat }\end{array}$ & $\begin{array}{l}\text { BEP* per kg } \\
\text { of } L W^{* *} \text { with } \\
25 \% \text { increase } \\
\text { over the } \\
\text { existing } \\
\text { production of } \\
\text { meat }\end{array}$ & $\begin{array}{l}\text { BEP* per kg } \\
\text { of } \mathrm{LW} * * \text { with } \\
25 \% \text { decrease } \\
\text { over the } \\
\text { existing } \\
\text { production of } \\
\text { meat }\end{array}$ & $\begin{array}{l}\text { BEP* per kg } \\
\text { of } \mathrm{LW} * * \text { with } \\
50 \% \text { increase } \\
\text { over the } \\
\text { existing } \\
\text { production of } \\
\text { meat }\end{array}$ & $\begin{array}{l}\text { BEP* per kg } \\
\text { of } L W * * \text { with } \\
50 \% \text { decrease } \\
\text { over the } \\
\text { existing } \\
\text { production of } \\
\text { meat }\end{array}$ & $\begin{array}{c}\text { Average } \\
\text { price } \\
\text { received } \\
\text { per kg of } \\
\text { LW** }\end{array}$ \\
\hline \multirow[t]{2}{*}{ Group I } & 66.64 & 60.58 & 74.05 & 53.31 & 88.86 & 44.43 & 133.28 & 75.00 \\
\hline & $(143.54)$ & $(130.49)$ & (159.48) & (114.83) & (191.38) & (95.69) & (287.07) & (161.54) \\
\hline \multirow[t]{2}{*}{ Group II } & 64.18 & 58.35 & 71.31 & 51.34 & 85.57 & 42.79 & 128.36 & 75.00 \\
\hline & (138.23) & (125.66) & (153.59) & (110.58) & (184.31) & $(92.15)$ & $(276.46)$ & (161.54) \\
\hline \multirow[t]{2}{*}{$\begin{array}{c}\text { Group } \\
\text { III }\end{array}$} & 62.70 & 57.00 & 69.66 & 50.16 & 83.59 & 41.80 & 125.39 & 75.00 \\
\hline & $(135.40)$ & (123.10) & $(150.45)$ & (108.32) & (180.54) & (90.27) & $(270.81)$ & (162.00) \\
\hline \multirow[t]{2}{*}{$\begin{array}{l}\text { Group } \\
\text { IV }\end{array}$} & 60.59 & 55.08 & 67.33 & 48.47 & 80.79 & 40.40 & 121.19 & 75.00 \\
\hline & $(132.78)$ & $(120.71)$ & (147.53) & $(106.22)$ & (177.04) & $(88.52)$ & $(265.56)$ & $(164.25)$ \\
\hline \multirow[t]{2}{*}{ Pooled } & 61.88 & 56.26 & 68.76 & 49.50 & 82.51 & 41.25 & 123.76 & 75.00 \\
\hline & $(134.66)$ & $(122.42)$ & (149.62) & (107.73) & $(179.55)$ & (89.77) & $(269.32)$ & $(163.50)$ \\
\hline
\end{tabular}

BEP* indicate break even price in rupees

$\mathrm{LW}^{* *}$ indicate live weight

Figures within parentheses indicate break even price per whole bird 
Table.5 Break even production of meat (live weight basis) per cycle with 5,10 and 15 per cent increase and decrease in the existing average price per kilogram of broiler meat across different size groups of sample broiler farms (kilogram)

\begin{tabular}{|c|c|c|c|c|c|c|c|c|}
\hline $\begin{array}{c}\text { Size } \\
\text { group }\end{array}$ & $\begin{array}{l}\text { BEPn* with } \\
\text { existing } \\
\text { average price } \\
\text { per kilogram } \\
\text { of live weight }\end{array}$ & $\begin{array}{l}\text { BEPn* with } \\
5 \% \text { increase } \\
\text { over the } \\
\text { existing } \\
\text { average } \\
\text { price }\end{array}$ & $\begin{array}{l}\text { BEPn* with } \\
5 \% \text { decrease } \\
\text { over the } \\
\text { existing } \\
\text { average price }\end{array}$ & $\begin{array}{l}\text { BEPn* with } \\
10 \% \\
\text { increase over } \\
\text { the existing } \\
\text { average } \\
\text { price }\end{array}$ & $\begin{array}{l}\text { BEPn* with } \\
10 \% \text { decrease } \\
\text { over the } \\
\text { existing } \\
\text { average price }\end{array}$ & $\begin{array}{l}\text { BEPn* with } \\
15 \% \\
\text { increase over } \\
\text { the existing } \\
\text { average } \\
\text { price }\end{array}$ & $\begin{array}{l}\text { BEPn* with } \\
\text { 15\% decrease } \\
\text { over the } \\
\text { existing } \\
\text { average price }\end{array}$ & $\begin{array}{l}\text { Average } \\
\text { production in } \\
\text { one cycle (kg } \\
\text { live weight) }\end{array}$ \\
\hline \multirow[t]{3}{*}{ Group I } & 6866.90 & 5277.44 & 9826.44 & 4285.49 & 17269.20 & 3607.44 & 71190.38 & 20892.40 \\
\hline & $(274.68)$ & (211.10) & (393.06) & (171.42) & (690.77) & (144.30) & $(2847.62)$ & (835.70) \\
\hline & $* 0.71$ & $* 0.54$ & $* 1.01$ & $* 0.44$ & $* 1.78$ & $* 0.37$ & $* 7.34$ & $* 2.15$ \\
\hline \multirow[t]{3}{*}{ Group II } & 20406.42 & 16577.52 & 26535.27 & 13958.46 & 37925.89 & 12054.06 & 66450.78 & 61167.40 \\
\hline & (784.86) & $(637.60)$ & (1020.59) & (536.86) & (1458.69) & $(463.62)$ & $(2555.80)$ & (2352.59) \\
\hline & $* 0.72$ & $* 0.58$ & $* 0.93$ & $* 0.49$ & $* 1.34$ & $* 0.42$ & $* 2.34$ & $* 2.15$ \\
\hline \multirow{3}{*}{$\begin{array}{l}\text { Group } \\
\text { III }\end{array}$} & 37172.60 & 30399.33 & 47829.51 & 25713.95 & 67052.61 & 22279.98 & 112111.06 & 138221.10 \\
\hline & (1429.72) & (1169.20) & (1839.60) & (989.00) & (2578.95) & $(856.92)$ & (4311.96) & (5316.20) \\
\hline & $* 0.58$ & $* 0.47$ & $* 0.75$ & $* 0.40$ & $* 1.05$ & $* 0.35$ & $* 1.75$ & $* 2.16$ \\
\hline \multirow{3}{*}{$\begin{array}{c}\text { Group } \\
\text { IV }\end{array}$} & 56534.08 & 46855.24 & 71252.67 & 40006.06 & 96332.83 & 34903.89 & 148659.27 & 273920.40 \\
\hline & $(2458.00)$ & (2037.18) & (3097.94) & (1739.39) & (4188.38) & (1517.56) & $(6463.45)$ & (11909.58) \\
\hline & $* 0.45$ & $* 0.37$ & $* 0.57$ & $* 0.32$ & $* 0.77$ & $* 0.28$ & $* 1.19$ & $* 2.19$ \\
\hline \multirow[t]{3}{*}{ Pooled } & 119545.32 & 98253.89 & 152617.16 & 83400.06 & 210985.71 & 72447.57 & 341650.01 & 494201.30 \\
\hline & $(1195.45)$ & (982.54) & (1526.17) & $(834.00)$ & $(2109.86)$ & $(724.48)$ & $(3416.50)$ & (4942.01) \\
\hline & $* 0.53$ & $* 0.43$ & $* 0.67$ & $* 0.37$ & $* 0.93$ & $* 0.32$ & $* 1.50$ & $* 2.18$ \\
\hline
\end{tabular}

BEPn*indicate break even production.

Figures in parenthesis indicate break even production of meat per farm.

*indicates break even production of meat per bird in $\mathrm{Kg}$ 
Table.6 Break even quantity (number) of bird per cycle with 5,10 and 15 per cent increase and decrease in the existing average price per bird across different size groups of sample broiler farms (number)

\begin{tabular}{|c|c|c|c|c|c|c|c|c|}
\hline $\begin{array}{c}\text { Size } \\
\text { group }\end{array}$ & $\begin{array}{c}\text { BEQ* with } \\
\text { existing } \\
\text { average price } \\
\text { per bird }\end{array}$ & $\begin{array}{c}\text { BEQ* with } \\
5 \% \text { increase } \\
\text { over the } \\
\text { existing } \\
\text { average } \\
\text { price }\end{array}$ & $\begin{array}{l}\text { BEQ* with } \\
5 \% \text { decrease } \\
\text { over the } \\
\text { existing } \\
\text { average price }\end{array}$ & $\begin{array}{c}\text { BEQ* with } \\
10 \% \\
\text { increase over } \\
\text { the existing } \\
\text { average } \\
\text { price }\end{array}$ & $\begin{array}{c}\text { BEQ* with } \\
10 \% \\
\text { decrease over } \\
\text { the existing } \\
\text { average price }\end{array}$ & $\begin{array}{c}\text { BEQ* with } \\
15 \% \\
\text { increase over } \\
\text { the existing } \\
\text { average } \\
\text { price }\end{array}$ & $\begin{array}{l}\text { BEQ* with } \\
\text { 15\% decrease } \\
\text { over the } \\
\text { existing } \\
\text { average price }\end{array}$ & $\begin{array}{c}\text { Average } \\
\text { production of } \\
\text { bird in one } \\
\text { cycle (number) }\end{array}$ \\
\hline \multirow[t]{2}{*}{ Group I } & 3188.19 & 2450.23 & 4562.25 & 1989.68 & 8017.81 & 1674.87 & 33052.53 & 9700 \\
\hline & (127.53) & (98.01) & (182.49) & (79.59) & $(320.71)$ & (66.99) & (1322.10) & (388.00) \\
\hline \multirow[t]{2}{*}{ Group II } & 9474.69 & 7696.94 & 12320.31 & 6480.91 & 17608.98 & 5596.69 & 30853.07 & 28400 \\
\hline & $(364.41)$ & (296.04) & $(473.86)$ & $(249.27)$ & $(677.27)$ & $(215.26)$ & (1186.66) & (1092.31) \\
\hline \multirow[t]{2}{*}{ Group III } & 17211.89 & 14075.69 & 22146.32 & 11906.23 & 31047.12 & 10316.22 & 51910.37 & 64000 \\
\hline & $(662.00)$ & $(541.37)$ & $(851.78)$ & (457.93) & (1194.12) & (396.78) & (1996.55) & $(2461.54)$ \\
\hline \multirow[t]{2}{*}{ Group IV } & 25798.59 & 21381.78 & 32515.23 & 18256.24 & 43960.23 & 15927.94 & 67838.72 & 125000 \\
\hline & (1121.68) & (929.64) & (1413.71) & (793.75) & (1911.31) & $(692.52)$ & (2949.51) & (5434.78) \\
\hline \multirow[t]{2}{*}{ Pooled } & 54934.58 & 45150.55 & 70132.07 & 38324.77 & 96954.13 & 33291.79 & 156998.21 & 227100 \\
\hline & $(549.35)$ & $(451.51)$ & $(701.32)$ & (383.25) & (969.54) & (332.92) & (1569.98) & (2271.00) \\
\hline
\end{tabular}

BEQ*indicate break even quantity of birds in number.

Figures in parenthesis indicate break even quantity of bird per farm. 
Table.7 Break even volume of meat with 10, 25 and 50 per cent increase and decrease in the existing average price per kilogram of broiler meat across different size groups of sample broiler farms (Kilogram)

\begin{tabular}{|c|c|c|c|c|c|c|c|c|}
\hline $\begin{array}{l}\text { Size } \\
\text { group }\end{array}$ & $\begin{array}{c}\text { BEV* with } \\
\text { existing } \\
\text { average price } \\
\text { per kilogram } \\
\text { of live weight }\end{array}$ & $\begin{array}{l}\text { BEV* with } \\
10 \% \text { increase } \\
\text { over the } \\
\text { existing } \\
\text { average price }\end{array}$ & $\begin{array}{l}\text { BEV* with } \\
10 \% \text { decrease } \\
\text { over the } \\
\text { existing } \\
\text { average price }\end{array}$ & $\begin{array}{l}\text { BEV* with } \\
25 \% \text { increase } \\
\text { over the } \\
\text { existing } \\
\text { average price }\end{array}$ & $\begin{array}{l}\text { BEV* with } \\
25 \% \text { decrease } \\
\text { over the } \\
\text { existing } \\
\text { average price }\end{array}$ & $\begin{array}{l}\text { BEV* with } \\
50 \% \text { increase } \\
\text { over the } \\
\text { existing } \\
\text { average price }\end{array}$ & $\begin{array}{l}\text { BEV* with } \\
50 \% \text { decrease } \\
\text { over the } \\
\text { existing } \\
\text { average price }\end{array}$ & $\begin{array}{c}\text { Average } \\
\text { production per } \\
\text { year (kg live } \\
\text { weight) }\end{array}$ \\
\hline \multirow[t]{2}{*}{ Group I } & 19634.72 & 17849.75 & 21816.36 & 15707.78 & 26179.63 & 13089.81 & 39269.44 & 167139.20 \\
\hline & (785.39) & (713.99) & $(872.65)$ & $(628.31)$ & (1047.19) & $(523.59)$ & (1570.78) & $(6685.57)$ \\
\hline \multirow[t]{2}{*}{ Group II } & 67744.96 & 61586.32 & 75272.17 & 54195.96 & 90326.61 & 45163.30 & 135489.91 & 489339.20 \\
\hline & $(2605.58)$ & $(2368.70)$ & (2895.08) & (2084.46) & $(3474.10)$ & (1737.05) & $(5211.15)$ & (18820.74) \\
\hline \multirow{2}{*}{$\begin{array}{l}\text { Group } \\
\text { III }\end{array}$} & 150663.60 & 136966.91 & 167404.00 & 120530.88 & 200884.80 & 100442.40 & 301327.19 & 1105768.80 \\
\hline & $(5794.75)$ & $(5267.96)$ & $(6438.62)$ & $(4635.80)$ & (7726.34) & $(3863.17)$ & (11589.51) & (42529.57) \\
\hline \multirow{2}{*}{$\begin{array}{l}\text { Group } \\
\text { IV }\end{array}$} & 228133.18 & 207393.80 & 253481.31 & 182506.54 & 304177.57 & 152088.78 & 456266.35 & 2191363.20 \\
\hline & (9918.83) & (9017.12) & (11020.93) & (7935.07) & (13225.11) & $(6612.56)$ & (19837.67) & (95276.66) \\
\hline \multirow[t]{2}{*}{ Pooled } & 466176.45 & 423796.77 & 517973.83 & 372941.16 & 621568.60 & 310784.30 & 932352.90 & 3953610.40 \\
\hline & $(4661.76)$ & (4237.97) & (5179.74) & (3729.41) & $(6215.69)$ & (3107.84) & (9323.53) & (39536.10) \\
\hline
\end{tabular}

$\mathrm{BEV} *$ indicate break even volume.

Figures within parentheses indicate values per farm 
Table.8 Break even years in broiler production with 10, 25 and 50 per cent increase and decrease in the existing average price per kilogram of broiler meat across different size groups of sample broiler farms (Number)

\begin{tabular}{|c|c|c|c|c|c|c|c|c|}
\hline Size group & $\begin{array}{l}\text { No. of } \\
\text { farms }\end{array}$ & $\begin{array}{c}\text { BEY* with } \\
\text { existing } \\
\text { average price } \\
\text { per kilogram } \\
\text { of live weight }\end{array}$ & $\begin{array}{l}\text { BEY* with } \\
10 \% \text { increase } \\
\text { over the } \\
\text { existing } \\
\text { average price }\end{array}$ & $\begin{array}{l}\text { BEY* with } \\
10 \% \text { decrease } \\
\text { over the } \\
\text { existing } \\
\text { average price }\end{array}$ & $\begin{array}{l}\text { BEY* with } \\
25 \% \text { increase } \\
\text { over the } \\
\text { existing } \\
\text { average price }\end{array}$ & $\begin{array}{l}\text { BEY* with } \\
25 \% \text { decrease } \\
\text { over the } \\
\text { existing } \\
\text { average price }\end{array}$ & $\begin{array}{l}\text { BEY* with } \\
50 \% \text { increase } \\
\text { over the } \\
\text { existing } \\
\text { average price }\end{array}$ & $\begin{array}{l}\text { BEY* with } \\
50 \% \text { decrease } \\
\text { over the } \\
\text { existing } \\
\text { average price }\end{array}$ \\
\hline \multirow[t]{2}{*}{ Group I } & 25 & 0.12 & 0.11 & 0.13 & 0.09 & 0.16 & 0.08 & 0.23 \\
\hline & & (1.41) & $(1.28)$ & (1.57) & (1.13) & (1.88) & $(0.94)$ & $(2.82)$ \\
\hline \multirow[t]{2}{*}{ Group II } & 26 & 0.14 & 0.13 & 0.15 & 0.11 & 0.18 & 0.09 & 0.28 \\
\hline & & (1.66) & $(1.51)$ & $(1.85)$ & (1.33) & $(2.22)$ & (1.11) & $(3.32)$ \\
\hline \multirow[t]{2}{*}{ Group III } & 26 & 0.14 & 0.12 & 0.15 & 0.11 & 0.18 & 0.09 & 0.27 \\
\hline & & (1.64) & $(1.49)$ & $(1.82)$ & $(1.31)$ & $(2.18)$ & $(1.09)$ & $(3.27)$ \\
\hline \multirow[t]{2}{*}{ Group IV } & 23 & 0.10 & 0.09 & 0.12 & 0.08 & 0.14 & 0.07 & 0.21 \\
\hline & & $(1.25)$ & (1.14) & (1.39) & $(1.00)$ & (1.67) & $(0.83)$ & $(2.50)$ \\
\hline \multirow[t]{2}{*}{ Pooled } & 100 & 0.12 & 0.11 & 0.13 & 0.09 & 0.16 & 0.08 & 0.24 \\
\hline & & (1.41) & $(1.29)$ & (1.57) & (1.13) & $(1.89)$ & $(0.94)$ & $(2.83)$ \\
\hline
\end{tabular}

BEY*indicate break even year.

Figures within parentheses indicate values in month 
Table.9 Investment appraisal of sample broiler farms in terms of pay back period (PBP), net present value (NPV), internal rate of return (IRR) and benefit cost ratio (BCR) under changing scenario of costs and returns

\begin{tabular}{|c|c|c|c|c|c|}
\hline \multirow[t]{2}{*}{ Size group } & \multirow{2}{*}{$\begin{array}{l}\text { Cost and return } \\
\text { scenario }\end{array}$} & \multicolumn{4}{|c|}{ Investment appraisal tools } \\
\hline & & Pay back period (years) & $\begin{array}{l}\text { Net present value at } 9 \% \\
\text { discount rate (rupees) }\end{array}$ & $\begin{array}{l}\text { Internal rate of return } \\
\text { (percentage) }\end{array}$ & $\begin{array}{c}\text { Benefit cost ratio at } 9 \% \\
\text { discount rate }\end{array}$ \\
\hline \multirow[t]{4}{*}{ Group I } & Existing situation & 1.39 & 312444.15 & 72.12 & 1.07 \\
\hline & Situation I & 3.07 & 100378.69 & 31.20 & 1.02 \\
\hline & Situation II & 3.45 & 81014.83 & 27.17 & 1.02 \\
\hline & Situation III & $*$ & -131050.64 & $*$ & 0.97 \\
\hline \multirow[t]{4}{*}{ Group II } & Existing situation & 1.23 & 1213711.15 & 82.20 & 1.10 \\
\hline & Situation I & 2.06 & 657736.78 & 48.06 & 1.05 \\
\hline & Situation II & 2.25 & 562852.56 & 44.12 & 1.05 \\
\hline & Situation III & 8.26 & 6878.19 & 12.88 & 1.00 \\
\hline \multirow[t]{4}{*}{ Group III } & Existing situation & 1.09 & 3149386.33 & 92.02 & 1.11 \\
\hline & Situation I & 1.68 & 1919378.37 & 60.15 & 1.07 \\
\hline & Situation II & 1.82 & 1677027.96 & 55.01 & 1.06 \\
\hline & Situation III & 4.45 & 447020.01 & 22.19 & 1.02 \\
\hline \multirow[t]{4}{*}{ Group IV } & Existing situation & 0.68 & 9123125.66 & 147.02 & 1.16 \\
\hline & Situation I & 0.95 & 6327517.29 & 106.06 & 1.11 \\
\hline & Situation II & 1.02 & 5829088.13 & 99.11 & 1.10 \\
\hline & Situation III & 1.75 & 3033479.76 & 57.08 & 1.05 \\
\hline \multirow[t]{4}{*}{ All farms } & Existing situation & 0.85 & 3304625.68 & 117.02 & 1.13 \\
\hline & Situation I & 1.24 & 2122866.66 & 80.10 & 1.08 \\
\hline & Situation II & 1.34 & 1935465.65 & 74.10 & 1.08 \\
\hline & Situation III & 2.67 & 753706.63 & 36.30 & 1.03 \\
\hline
\end{tabular}

Situation I: Increase in costs by $5 \%$.

Situation II: Decrease in returns by $5 \%$.

Situation III: Increase in cost by $5 \%$ \& decrease in returns by $5 \%$ simultaneously.

$*=$ Indeterminable 
Break even quantity (number) of whole bird per cycle across different size groups of sample broiler farms is furnished in Table 6 . It could be observed from the table that on an average break even quantity (number) of birds to be maintained with existing average price received per bird was 549.35 per farm in the entire sample in one cycle to meet all the costs incurred in broiler production, while average number of birds maintained per farm per cycle was 2271.00 numbers in the sample. Thus it shows that the broiler farmers were maintaining well above the break even level of birds.

A perusal of the sensitivity analysis however brought out the fact that all the farms stand viable up to $10 \%$ decrease in the existing average price received per bird per cycle. However, Group I and II operate below the break even level, when the price falls below $15 \%$ of the existing average price, while Group III and IV still remains economically viable in the business operating above break even level. At $15 \%$ decrease in the existing price, farms in Group I and II needs to maintain 1322.10 and 1186.66 numbers of birds respectively, while the average existing production in the groups were 388.00 and 1092.31 respectively.

\section{Break even volume of meat production in broiler farming}

Break even volume is the minimum level of production that is required to recover the initial investment in any enterprise. Table 7 shows the details of break even volume of meat across different size groups of sample broiler farms. It could be observed from the table that break even volume of meat in the entire sample was 466176.45 kilograms and per farm break even volume was 4661.76 kilogram, while the average production of meat per cycle was 494201.30 kilogram and hence average production per year was computed to be 3953610.40 kilogram and per farm annual average production was 39536.10 kilogram. Therefore it is clear that average production of meat per year was much higher than the volume of meat to be produced in a year to get break even point of the business in terms of initial investment.

In regard to sensitivity analysis, data from the table reveal that, all the farms in all size groups could recover the investment cost within a year even if the price falls below $50 \%$ of the existing average price as average volume of meat produced by all the farms were much higher than their respective break even values up to $50 \%$ decrease in the existing price.

\section{Break even years in broiler farming}

Break even years in the study is defined as the number of years required to cover initial investments made in the enterprise. Data from Table 8 show that break even years in broiler production across different size group of sample broiler farms reveal that the number of years required for break even for the entire sample was 0.12 (1.41 months). Thus, a farm may recover its investment cost in less than 2 months of commencing the business in ideal condition. Sensitivity analysis also shows that, even at $50 \%$ decrease in the existing price, entire sample on an average could cover the investment cost in around 3 months. All the farms in all size groups could recover the investment cost within around 3 months period even at $50 \%$ decrease in existing price. This indicates that returns can be achieved quite earlier in broiler farming business. Faster return and lesser requirement of time in recovering initial investment might also owe to low initial investments in broiler farming. These attributes are rendering broiler farming a popular business among farmers in recent times. 
Effect of changes in cost of input and return from output on investment appraisal tools

The profitability of investment in broiler farming was also evaluated by computing Pay Back Period (PBP), Net Present Value (NPV), Benefit Cost Ratio (BCR) and Internal Rate of Return (IRR) of the sample broiler farms in the present study. The financial soundness of broiler farming was examined by analyzing the cash flow during the assumed life of the broiler farms. The cash flow analysis of the broiler farms was conducted twice; one in the existing situation of price and cost structure and the second under circumstances of decreased net cash flow on account of decline in gross returns and increase in gross cost etc. As a part of sensitivity analysis, results of the cash flow analysis under existing and assumed situations of net cash flow were compared to see the competence of the farms in standing adverse situations of decreased cash flow. Thus, PBP, NPV, BCR and IRR were computed in existing as well as adverse situations to evaluate the viability of the farms under unfavourable situations of cost and price change. Sensitivity analysis was carried out for three situations i.e. PBP, NPV, BCR and IRR were calculated under three different situations of cost and return changes besides existing situation. Situation I at 5\% increase in gross cost, situation II at 5\% decrease in gross return and situation III at 5\% increase in cost and 5\% decrease in return simultaneously. Investment appraisal of sample broiler farms in terms of PBP, NP, IRR and BCR under changing scenario of costs and returns is presented in Table 9. Data from the table reveal that on an average in the existing situation farms in the sample took less than a year (0.85) to cover up the investment in broiler farming. However, on an average the PBP were computed as 1.24 , 1.34 and 2.67 years under situation of $5 \%$ increase in cost, $5 \%$ decrease in returns and simultaneous 5\% increase in cost and 5\% decrease in returns respectively for the sample as a whole. Since initial investment in broiler farming is less, thus, even if the cost and return structure go little unfavourable, it does not have much effect on PBP particularly in case of large farms. Farms in Group I however could not remain viable under situation III as its net cash flow rendered negative and they could not even recover the operational cost. Similarly, the NPV figures for all the farms except Group I under different situations of cost and return changes were positive indicating financial viability of the business. However, Group I farms would turn nonviable under situation III as their NPV would become negative. When calculated at discount rate of 9\% (prevailing term deposit rate as opportunity cost), IRR show satisfactory result in favour of all the farms under different situations of cost and return except Group I farms under situation III. IRR for the sample as a whole were computed as $117.02,80.10,74.10$ and 36.30 under existing situation, situation I, situation II and situation III respectively. Relatively higher internal rate of return observed in the study might be due to low initial investment in broiler farming. Since IRR is greater than the discount rate representing opportunity cost of capital under existing situation, farms of all four sizes were financially viable. However, IRR for group I farms could not be determined under situation III as net cash flow itself turned negative. Likewise, under situation III, IRR for Group II farms (12.88\%) was only marginally higher than the opportunity cost of capital $(09.00 \%)$, indicating low financial potency of these farms. Similarly BCR was also more than 1 for all farms under existing and assumed situations of cost and return changes except Group I farms under situation III. However, BCR under adverse cost and return scenario were only marginally greater than 1 in all the farms and is exactly 1 in case of farms in 
Group II. Thus the BCR figures indicate non viability of farms in Group I and II under situation of simultaneous increase in cost and decrease in return. Further, although Group III and Group IV farms were financially viable under different adverse cost and return scenario, their condition was also marginally above the benchmark particularly under situation III.

Thus, sensitivity analysis both in terms of break even study and investment appraisal indicated relatively more sensitiveness of smaller farms towards adverse cost, price and return scenario than the large sized farms. Although, larger farms remained economically viable under adverse cost and return scenario, however that competence was only to a limited extent and a greater degree of price and cost change would render them unviable too in the business.

In conclusion the effect of changes in production and price of output on break even values and effect of changes in costs of inputs and returns from output on the investment appraisal tools in broiler farming in Sonitpur district of Assam was evaluated in the present study. The result of the analysis brought to light that, changes in the structure of cost, price and production have a notable effect on the break even values and the values of PBP, NPV, BCR and IRR particularly on small sized farms. Break even analysis in the sample broiler farms brought out the fact that all farms in their existing condition were well above all the break even values in terms of price of meat and bird, production of meat, number of birds produced, volume of meat produced in a year and number of years required for break even. Average prices and production both in terms of birds and live weight basis, volume of meat produced per year and number of years required to cover the investment cost were much higher than their respective break even values. Sensitivity analysis in case of break even values reveal that even if the production in terms of meat and bird (number) and price of meat (live weight basis) and bird falls below 10 per cent of the existing productions and prices respectively, the farmers in the sample studied would still be able to operate above the break even level and thus would remain economically viable. Regarding the effect of changes in costs and returns on PBP, NPV, BCR and IRR, it may be concluded that the small sized broiler farms were highly sensitive to increase in costs and decrease in returns. Sensitivity analysis also reveals that investment in broiler farming was found to be most profitable in large farms, and such farms were relatively less sensitive to changes in costs and returns. This may be because of the reason that the cost of production per bird was lowest, while returns per bird were highest on large farms in contrast to the small farms. From the findings of the study it can be concluded that, although under normal situation, broiler farming is a profitable enterprise in Assam condition, however, adverse situations of fluctuations in cost, production and return could render the farms nonviable, particularly if the scale of operation is small. Thus, if farmers adopt broiler farming as primary and sole source of income, enough margin of safety over and above the break even values needs to be maintained in terms of production. This, way broiler farming both in principal and subsidiary status could pave the way for the state to occupy a parallel status with the progress made in agricultural and allied sectors in other states of the country.

\section{Acknowledgements}

Authors acknowledge the support provided by the Dept. of Agricultural Economics and F.M., Assam Agricultural University, Jorhat in conducting the research required for the preparation of this manuscript. 


\section{References}

Borah, M., And Halim, R.A. 2017. Profitability Analysis of Broiler Farms: A Case Study of Sonitpur District of Assam. Economic Affairs, 62(1): 23-32

Halim, R.A., and Chiste, S.M.T. 2000. Economics of Broiler Farming in Kamrup district of Assam. Journal of Interacademicia, 4 (2): 294-303.

Kalita, K.P. 2011. Byabasaik Bhittit Kukura Palan, Fourth edition. Shree moti Himashree Kalita, Beltola, Survey, Guwahati, Assam. p 80.
Kay, R.D. 1986. Farm Management Planning, Control and Implementation. McGrew Hil Book Co., Singapore, p. 255.

Reddy, S.S., Ram, P.R., Sastry, T.V.N., and Devi I.B. 2010. Agricultural Economics. Oxford \& IBH Publishing Co. Pvt. Ltd., New Delhi. pp 481- 482.

Singh, V.P., Sharma V.K., Sidhu, M.S., and Kingra, H.S. 2010. Broiler Production in Punjab - An Economic Analysis. Agricultural Economics Research Review, 23 (2): 315-324.

\section{How to cite this article:}

Monisha Borah and Halim, R. A. 2021. Sensitivity Analysis of Broiler Farming Enterprise under Changing Scenario of Costs, Prices and Yields in Assam. Int.J.Curr.Microbiol.App.Sci. 10(01): 1493-1509. doi: https://doi.org/10.20546/ijcmas.2021.1001.177 